\title{
Iron Transport in Mycobacterium smegmatis: Occurrence of Iron-regulated Envelope Proteins as Potential Receptors for Iron Uptake
}

\author{
By RICHARD M. HALL, $†$ MANJULA SRITHARAN, \\ ANN J. M. MESSENGER AND COLIN RATLEDGE* \\ Department of Biochemistry, University of Hull, Hull HU6 $7 R X, U K$
}

(Received 30 September 1986; revised 26 March 1987)

\begin{abstract}
Cell-envelope fractions were isolated from the rapidly growing saprophyte Mycobacterium smegmatis following growth in glycerol/asparagine medium under both iron-limited $\left(0.02 \mu \mathrm{g} \mathrm{Fe} \mathrm{ml}^{-1}\right)$ and iron-sufficient $\left(2.0\right.$ to $\left.4.0 \mu \mathrm{g} \mathrm{Fe} \mathrm{ml}^{-1}\right)$ conditions. Examination of these preparations by SDS-PAGE demonstrated the production of at least four additional proteins when iron was limiting. These iron-regulated envelope proteins (IREPs) were ascribed apparent molecular masses of $180 \mathrm{kDa}$ (protein I), $84 \mathrm{kDa}$ (protein II), $29 \mathrm{kDa}$ (protein III) and $25 \mathrm{kDa}$ (protein IV). All four proteins were present in both cell-wall and membrane preparations but spheroplast preparations were devoid of the $29 \mathrm{kDa}$ protein. Attempts at labelling the proteins with ${ }^{55} \mathrm{FeCl}_{3}$ or ${ }^{55} \mathrm{Fe}$-exochelin, the siderophore for iron uptake, were unsuccessful, though this was attributed to the denatured state of the proteins following electrophoresis. Antibodies were raised to each of the four proteins; the one raised to protein III inhibited exochelin-mediated iron uptake into iron-deficiently grown cells by $70 \%$ but was ineffective against iron uptake into iron-sufficiently grown cells. As exochelin is taken up into both types of cells by a similar process, protein III may not be a simple receptor for iron uptake though the results imply some function connected with this process. The role of the other IREPs is less certain.
\end{abstract}

\section{INTRODUCTION}

The extreme insolubility of ferric iron at neutral $\mathrm{pH}\left(10^{-15} \mathrm{M}\right.$ at $\left.\mathrm{pH} 7 \cdot 0\right)$ has led aerobic and facultative micro-organisms to evolve high-affinity iron transport systems which are derepressed under conditions of iron limitation. Iron chelators, termed siderophores, are synthesized and, when complexed with ferric iron, are taken up by cells (Neilands, 1981, 1982). Specific membrane protein receptors are produced by several micro-organisms for the transport of these complexes (Braun et al., 1976; Brown et al., 1984; Chart et al., 1986). The ability of pathogens to synthesize the receptor proteins under conditions of iron stress appears to be an important virulence factor (Griffiths, 1983, 1985). The expression of these iron-regulated proteins has also been demonstrated in bacteria grown in vivo: for example in those causing infections of the urinary tract (Lam et al., 1984; Shand et al., 1985), the cystic fibrotic lung (Brown et al., 1984) and the peritoneal cavity (Griffiths et al., 1983). The latter was the first direct evidence that bacteria growing in vivo do so under iron-limited conditions.

Mycobacterium smegmatis, as a saprophytic, fast-growing species, has proved to be a useful model organism for studying the essential features of iron metabolism in other members of this genus which include the pathogens $M$. tuberculosis and $M$. leprae. All mycobacteria produce a series of extracellular siderophores termed exochelins, as well as an intracellular lipid-soluble siderophore, mycobactin (Ratledge, 1982; Hall, 1986). Like other siderophores, both exochelin

† Present address: Glaxo Group Research, Department of Biotechnology, Greenford, Middlesex, UK.

Abbreviation: IREP, iron-regulated envelope protein. 
and mycobactin are produced in increased amounts in response to iron-limited growth. In addition, citrate can also act as an iron donor in both $M$. smegmatis and $M$. vaccae (Messenger \& Ratledge, 1982; Messenger $e t$ al., 1986) and uptake of ${ }^{55} \mathrm{Fe}$ complexed to rhodotorulic acid, but not to ferrioxamine or ferrichrome, has been demonstrated in $M$. smegmatis (A. J. M. Messenger, unpublished work). As the acquisition of iron from exochelin in M. smegmatis is an active transport process (Stephenson \& Ratledge, 1979), a specific receptor protein would be expected to occur if the parallel with the other bacterial systems were to be followed.

Normal human adult sera contain IgG antibodies against outer-membrane proteins of Escherichia coli (Griffiths, 1983; Griffiths et al., 1985), including the iron-regulated outermembrane proteins. Antibodies have also been raised to ferric-enterobactin receptor of $E$. coli (Chart \& Griffiths, 1985) and to ferri-pyochelin-binding protein of Pseudomonas aeruginosa (Sokol \& Woods, 1984); the latter antibody is able to block iron uptake in P. aeruginosa (Sokol \& Woods, 1986). In this paper, we demonstrate for the first time in mycobacteria several cell envelope proteins whose synthesis is regulated by iron. An antibody has been raised to each of these proteins, one of which blocks iron uptake from ferri-exochelin.

\section{METHODS}

Media and culture conditions. Mycobacterium smegmatis NCIB 8548 was grown in a simple glycerol/asparagine/ salts liquid medium ( $100 \mathrm{ml}$ in a $250 \mathrm{ml}$ conical flask) prepared as previously described for the removal of iron (Ratledge \& Hall, 1971) and shaken at $37^{\circ} \mathrm{C}$ at 200 r.p.m. for 3 to 7 d. For iron-sufficient conditions a supplement of 2.0 to $4.0 \mu \mathrm{g} \mathrm{Fe} \mathrm{ml}^{-1}$ was added. M. smegmatis was also grown under conditions of iron deprivation on solidified glycerol/asparagine medium where no prior treatment for the removal of iron was necessary (Hall \& Ratledge, 1982).

Preparation of cell envelope fraction. $M$. smegmatis cultures $(4 \times 100 \mathrm{ml})$, grown under conditions of either iron depletion or iron sufficiency, were harvested by centrifugation $(6000 \mathrm{~g})$ at $10^{\circ} \mathrm{C}$. Cells were suspended in approximately $100 \mathrm{ml} 0.05 \mathrm{M}-\mathrm{Tris} / \mathrm{HCl}$ buffer, $\mathrm{pH} \mathrm{7.8,} \mathrm{recentrifuged} \mathrm{and} \mathrm{resuspended} \mathrm{in} \mathrm{approximately} 15 \mathrm{ml}$ of the same buffer. The cell suspension was disrupted at $0^{\circ} \mathrm{C}$ by ultrasonication for $3 \mathrm{~min}(6 \times 30 \mathrm{~s})$ using a Dawe Soniprobe (type $7533 \mathrm{~A}$ ) operating at $30 \mathrm{kHz}$. The disrupted cells were centrifuged at $6000 \mathrm{~g}$ for $10 \mathrm{~min}$. The supernatant was centrifuged at $105000 \mathrm{~g}$ for $30 \mathrm{~min}$ at $6{ }^{\circ} \mathrm{C}$, washed with $0.05 \mathrm{M}$-Tris/ $\mathrm{HCl}$ buffer and recentrifuged for $30 \mathrm{~min}$. The pellet (cell-envelope fraction) was resuspended in approximately $10 \mathrm{ml} 2 \%(\mathrm{w} / \mathrm{v}$ ) SDS in $0.05 \mathrm{M}$ Tris $/ \mathrm{HCl}, \mathrm{pH} 6.8$, at room temperature for $15 \mathrm{~min}$ to extract envelope proteins and then recentrifuged $(105000 \mathrm{~g})$ for $30 \mathrm{~min}$. The supernatant solution was then used as the envelope protein extract and lyophilized before examination.

Preparation of spheroplasts. Spheroplasts were prepared from both iron-deficient and iron-sufficient cells by the method of Sadhu \& Gopinathan (1982), using lipase and lysozyme to degrade the cell-wall material of $\boldsymbol{M}$. smegmatis.

Preparation of wall and membrane fractions. Harvested cells were washed and ultrasonicated as described above. Cell debris was removed by centrifuging at $6000 \mathrm{~g}$ for $10 \mathrm{~min}$. The supernatant was centrifuged at $20000 \mathrm{~g}$ for $30 \mathrm{~min}$ to sediment the cell wall. The supernatant was then centrifuged at $105000 \mathrm{~g}$ for 60 to $90 \mathrm{~min}$. The pellets of both cell wall and membranes were washed twice with buffer and recentrifuged. The wall and membrane proteins were solubilized by treating the respective pellets with $2 \%(\mathrm{w} / \mathrm{v}) \mathrm{SDS}$ in $0.0625 \mathrm{M}-\mathrm{Tris} / \mathrm{HCl}$ buffer, $\mathrm{pH} 6.8$.

$S D S-P A G E$. Cell-envelope proteins were separated on vertical slab gels $(16 \times 18 \times 0.3 \mathrm{~cm})$ using a cooled chamber (BioRad-Protean Dual Slab gel). A 5 to $20 \%(\mathrm{w} / \mathrm{v})$ acrylamide gradient $(+3.5 \%$ stacker gel) with $0.2 \%$ $(w / v)$ methylene bisacrylamide and $0 \cdot 1 \%(w / v)$ SDS gave excellent separation (see Hames \& Rickwood, 1981). All reagents were $\mathrm{BDH}$ electrophoresis grade. Electrophoresis was routinely done at $30 \mathrm{~mA}$ per gel for approximately $3.5 \mathrm{~h}$. The buffer system was designed to dissociate all proteins into their individual polypeptide subunits and contained $\left(\mathrm{gl}^{-1}\right)$ glycine, 144; Tris, 30.3; SDS, 10; the buffer was diluted 1 in 10 for use. Protein mixtures were dissolved in buffer $(0.0625 \mathrm{M}$-Tris $/ \mathrm{HCl}, \mathrm{pH} 6.8 ; 2 \%, \mathrm{w} / \mathrm{v}, \mathrm{SDS} ; 10 \%, \mathrm{w} / \mathrm{v}$, sucrose and $0.002 \%$, w/v, bromophenol blue) and denatured by boiling for $3 \mathrm{~min}$ before application. A sample $(100 \mu \mathrm{l})$ containing approximately $100 \mu \mathrm{g}$ protein was applied to each well. Protein was determined by a modified Lowry procedure (Markwell et al., 1978). Gels were stained for $1 \mathrm{~h}$ in Serva blue $\mathrm{G}$ made up to $0.05 \%$ in acetic acid/methanol/water $(1: 5: 5$, by vol.) with destaining, usually overnight, in methanol/acetic acid/water $(50: 75: 875)$. Molecular mass standards included myosin (205 kDa), $\beta$-galactosidase (116 kDa), phosphorylase b (97 kDa), albumin (bovine) (66 kDa), albumin (egg) (45 kDa) and carbonic anhydrase $(29 \mathrm{kDa})$ (all from Sigma).

Preparative gel electrophoresis for isolating iron-regulated envelope proteins (IREPs). The method of Chart \& Griffiths (1985) was followed with some modifications. A sample of the cell envelope fraction ( $1 \mathrm{ml}$ ) containing $1 \mathrm{mg}$ protein was applied into a single well extending three-quarters the width of the gel. After electrophoresis (see 
above) the gel was stained in Serva blue for about 5 to $10 \mathrm{~min}$ to visualize the proteins. Those bands which were predominantly present only in cells which had been grown iron deficiently were cut out and macerated by passing each through a $10 \mathrm{ml}$ syringe (without a needle). Proteins were eluted by suspending the macerated gels in Tris/ $\mathrm{HCl}$ buffer $(0.05 \mathrm{M}, \mathrm{pH} 6.8)$ containing $2 \%(\mathrm{w} / \mathrm{v})$ SDS for 16 to $24 \mathrm{~h}$. The protein samples were then dialysed for $24 \mathrm{~h}$ against Tris/ $\mathrm{HCl}$ buffer $(0.05 \mathrm{M}, \mathrm{pH} \mathrm{6.8)}$ to remove the SDS. The samples were then lyophilized.

Dansylation of cell envelope proteins in situ. The method of Kinoshita et al. (1974) was followed using a cycloheptaamylose/dansyl chloride complex to label any $\mathrm{NH}_{2}$-groups of proteins exposed at the surface of cells.

Labelling of IREPs with ${ }^{55} \mathrm{Fe}$. After SDS-PAGE of the proteins from the envelope fraction, the gel was incubated overnight with either ${ }^{55} \mathrm{FeCl}_{3}$ (120000 c.p.m. added) or ${ }^{55} \mathrm{Fe}$-exochelin $(30000 \mathrm{c} . \mathrm{p} . \mathrm{m}$. added). The gel was washed, sliced into $1 \mathrm{~mm}$ sections and the ${ }^{55} \mathrm{Fe}$ retained counted by liquid scintillation.

Production of antisera. Polyclonal antisera to each of the four isolated IREPs were raised in male New Zealand White rabbits. About $200 \mu \mathrm{g}$ of each protein was emulsified in incomplete Freund's adjuvant (Guilday Antisera) and injected subcutaneously at multiple sites. After 3 weeks, a second injection, again in incomplete Freund's adjuvant, was given intramuscularly. Further booster injections were given in saline. Blood (about 20 to $30 \mathrm{ml}$ ) was collected from the marginal ear vein 3 to $4 \mathrm{~d}$ after the booster injection was given. Serum was separated after clot formation.

The total immunoglobulins (Igs) from the antisera and from normal rabbit serum was assayed for protein by the Lowry method, after precipitating the Igs with ammonium sulphate (Warr, 1982).

Uptake of iron from ${ }^{55} \mathrm{Fe}$-exochelin into $\mathrm{M}$. smegmatis in the presence of IREP-antibodies. Iron uptake was studied by the method of Stephenson \& Ratledge (1979) using ${ }^{55} \mathrm{Fe}$-exochelin from $M$. smegmatis prepared as described by Macham et al. (1977). The exochelin preparation used was a mixture, termed 'purified but unfractionated'. Briefly, washed cells of $M$. smegmatis were suspended in $50 \mathrm{mM}-\mathrm{KH}_{2} \mathrm{PO}_{4} / \mathrm{NaOH}$ buffer, $\mathrm{pH} 7 \cdot 1$, and preincubated with each specific antiserum or normal rabbit serum at $37^{\circ} \mathrm{C}$ for $30 \mathrm{~min}$. ${ }^{55} \mathrm{Fe}$-exochelin $(1 \mu \mathrm{M})$ was added to the reaction mixture and incubation continued for $10 \mathrm{~min}$. Iron uptake was stopped by adding $1 \mathrm{ml} 50 \mathrm{mm-EDTA}$ to each reaction mixture. The solutions were then rapidly filtered through $2.5 \mathrm{~cm}$ glassfibre filters (Whatman $\mathrm{GF} / \mathrm{C}$ ) using a Millipore multiport filtration unit. The cells were washed three times with $2 \mathrm{ml} 50 \mathrm{~mm}$-EDTA. The filters were then placed in glass scintillation vials and $0.5 \mathrm{ml}$ tissue solubilizer ('NCS' from Amersham) was added to each vial and the cells were digested at $50^{\circ} \mathrm{C}$ for $1 \mathrm{~h}$. The mixure was neutralized with glacial acetic acid $(50 \mu \mathrm{g})$ and scintillation fluid $(10 \mathrm{ml})$ containing $0.5 \%(\mathrm{w} / \mathrm{v})$ PPO and $0.05 \%(\mathrm{w} / \mathrm{v})$ POPOP in toluene was added. The ${ }^{55} \mathrm{Fe}$ retained by the filter was counted in a liquid scintillation counter and the results expressed as c.p.m. (mg dry wt cells) $)^{-1}$.

\section{RESULTS AND DISCUSSION}

\section{Effect of iron limitation on cell envelope proteins}

When grown under conditions of iron limitation, $M$. smegmatis synthesized several cellenvelope proteins which were repressed in cells grown iron sufficiently (Fig. 1). Using SDSPAGE, four IREPs were recognized in preparations from iron deficient cells with apparent molecular masses corresponding, on repeated runs, to I $=180 \mathrm{kDa} ; \mathrm{II}=84 \mathrm{kDa}$; III $=29 \mathrm{kDa}$ and IV $=25 \mathrm{kDa}$ (Fig. 1). Of these, II and III were the major proteins and were observed in cells harvested from $3 \mathrm{~d}$ (early growth phase) to $7 \mathrm{~d}$ (stationary phase) in both liquid glycerol/asparagine medium and the same medium solidified with agar. Their expression corresponded with the onset of iron limitation as marked by the simultaneous appearance of the mycobacterial siderophores, mycobactin and exochelin.

\section{Determination of the possible location of iron-specific proteins within the cell envelope}

To study the location of the iron-regulated envelope proteins within the cell envelope, cell-wall and membrane fractions were analysed separately by SDS-PAGE. All the four IREPs were evident in both cell-wall and cell-membrane extracts. Next, spheroplasts were prepared from iron-deficient and iron-sufficient cells and the membrane proteins isolated as before and examined by SDS-PAGE. It was essential to use cells which had been grown for at least $3 \mathrm{~d}$ to ensure complete iron deprivation. Of the four IREPs, all except protein III $(29 \mathrm{kDa})$ were evident after SDS-PAGE of extracts from spheroplasts of iron-deficiently grown cells. [Like Sadhu \& Gopinathan (1982) we have used the term spheroplast rather than protoplast for our preparation, as we cannot be sure that some wall material does not remain attached to the membrane.] The failure to detect protein III in preparations of membranes from spheroplasts but not from membranes prepared from whole cells is not fully understood. It may, though, indicate that protein III has a different location from the other IREPs. 
A

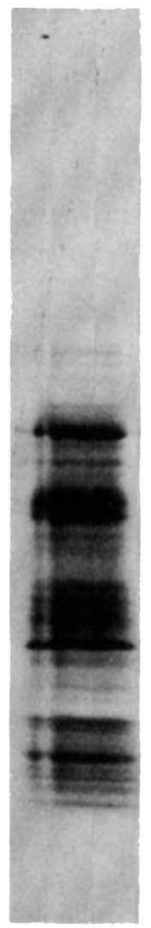

B

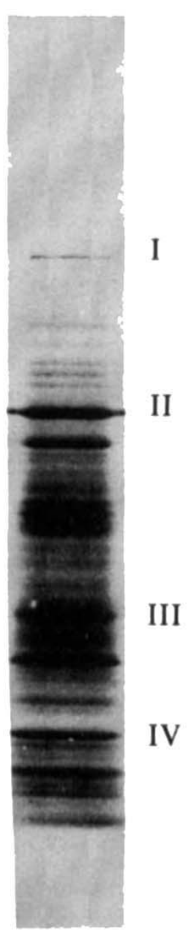

Fig. 1

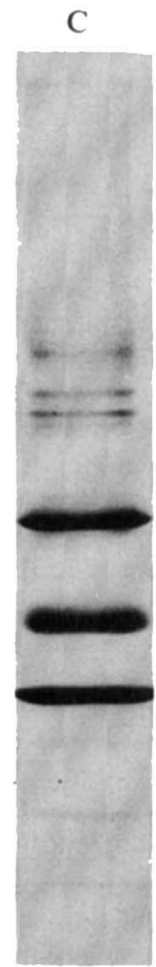

A

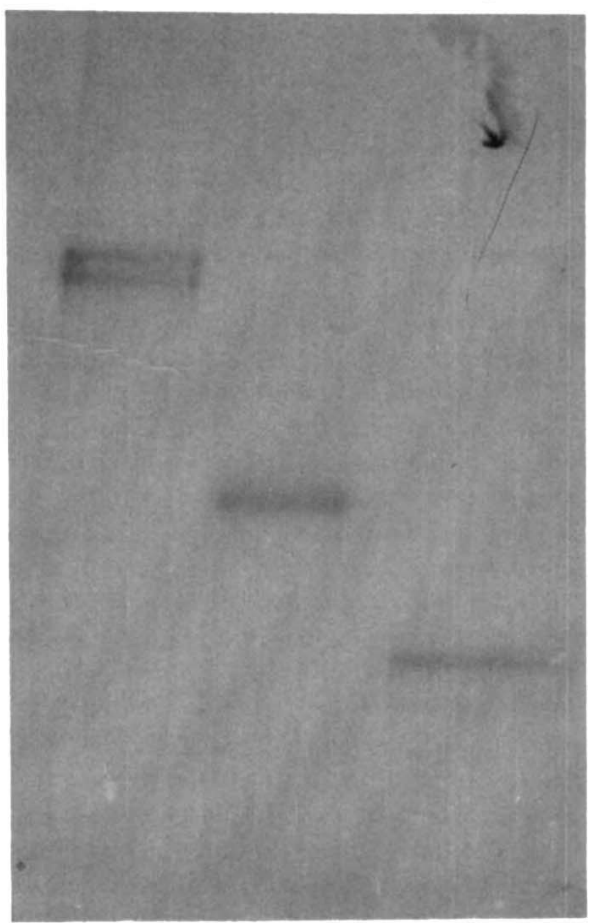

Fig. 2

Fig. 1. SDS-PAGE profiles of cell-envelope proteins $(100 \mu \mathrm{g}$ per lane $)$ from cells grown ironsufficiently (lane A) and iron-deficiently (lane B). Lane C shows the profile of the molecular mass markers. The numbers I to IV indicate protein I (180 kDa), protein II ( $84 \mathrm{kDa})$, protein III $(29 \mathrm{kDa})$ and protein IV $(25 \mathrm{kDa})$ respectively.

Fig. 2. SDS-PAGE of isolated IREPs from gels similar to those shown in Fig. 1. Lane A, protein II; lane B, protein III; lane C, protein IV. (Protein I gave a faint single band - not shown.)

Though all the four IREPs were found to be present in cell-wall preparations, none of them were dansylated after applying the method of Kinoshita et al. (1974) to whole cells grown iron deficiently. This, however, does not necessarily imply that these proteins are not exposed at the surface of the cell, only that they do not have an $\mathrm{NH}_{2}$ group, of either a protein terminal amino acid or lysine residue, exposed.

None of the IREPs, however, were considered to be associated with peptidoglycan itself as treatment of envelope protein (i.e. wall and membrane) with $2 \%(\mathrm{w} / \mathrm{v}) \mathrm{SDS}$ in $0.05 \mathrm{M}-\mathrm{Tris} / \mathrm{HCl}$ at four temperatures $\left(25,37,66\right.$ and $100^{\circ} \mathrm{C}$ ) all resulted in release of the four IREPs (which were identified by SDS-PAGE).

The location of three of the four IREPs, I, II and IV, would appear to be both within the cytoplasmic membrane as well as the cell wall; that of protein III would appear to be within the cell wall though some association with membrane preparations is indicated by some of the results.

\section{Attempted labelling of IREPs with ${ }^{55} \mathrm{Fe}$}

Labelling of an iron-regulated outer-membrane protein with labelled ferri-siderophore has been reported by Sokol \& Woods (1983) for Pseudomonas aeruginosa. However, attempts to label the IREPs from iron-deficiently grown cells of $M$. smegmatis were unsuccessful using both ${ }^{55} \mathrm{FeCl}_{3}$ and ${ }^{55} \mathrm{Fe}$-exochelin. Although there was no significant binding of ${ }^{55} \mathrm{Fe}$ by any of the membrane proteins, this would not exclude their possible role as receptors for ferri-exochelins as 


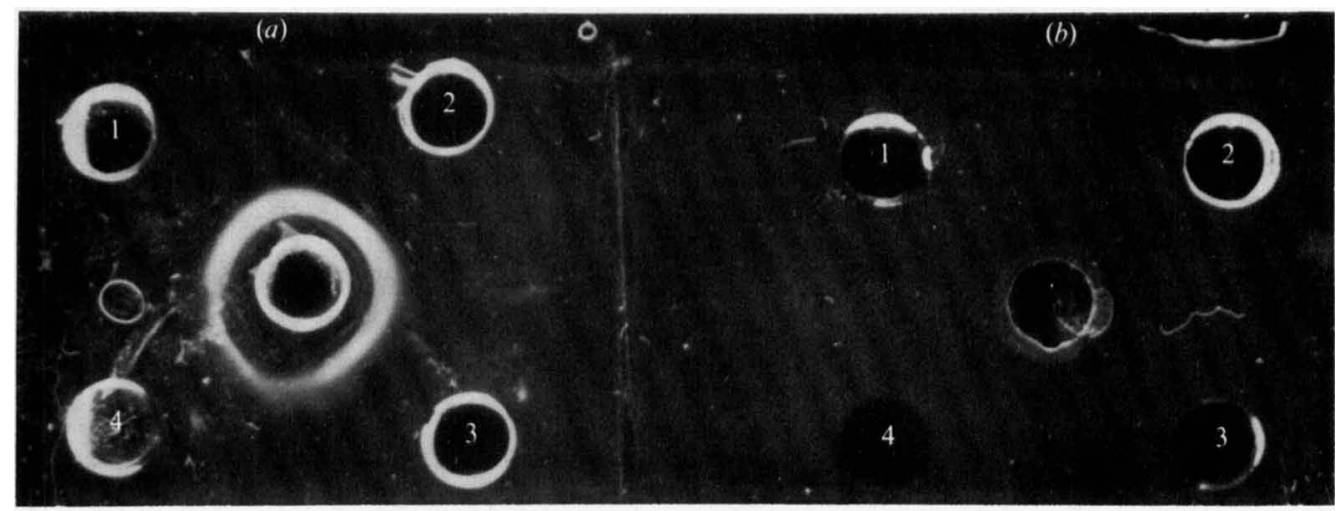

Fig. 3 Ouchterlony double diffusion analysis of cell-envelope proteins from iron-deficiently grown cells $(a)$ and iron-sufficiently grown cells $(b)$ against antiserum raised to protein III. The centre wells contained the undiluted antiserum while the four peripheral wells contained serial dilutions of the envelope proteins at a concentration of $1 \mathrm{mg} \mathrm{ml}^{-1}$ : well $1,1: 10$; well $2,1: 20$; well $3,1: 40 ;$ well $4,1: 80$.

the proteins, being in SDS, would have been in a denatured state. Clearly, the conformation of the IREPs must be important if they are subsequently shown to be receptors for ferri-exochelin. Attempts were also made to label the IREPs whilst still in situ (i.e. before disruption of the cells) with ${ }^{55} \mathrm{FeCl}_{3}$ and ${ }^{55} \mathrm{Fe}$-exochelin, but again no ${ }^{55} \mathrm{Fe}$ could be recovered in the proteins after SDS-PAGE. As before, this failure could be due to loss of the necessary three-dimensional integrity of the proteins by the denaturing conditions of electrophoresis in the presence of SDS.

\section{Antibodies against the IREPS}

The four principal IREPs were isolated by preparative gel electrophoresis from 5-d-old cultures of $\boldsymbol{M}$. smegmatis. Protein III when re-examined by SDS-PAGE migrated as a single band (Fig. 2); protein II appeared as a doublet and protein IV showed the presence of a minor contaminating protein. Protein I, not shown in Fig. 2, gave only a single faint band. The antibodies raised against each of these four proteins were tested by the gel double diffusion method of Ouchterlony (Wang, 1982) against extracts prepared from both iron-deficient and iron-sufficient cells. Of the four IREPs, only protein III was produced by iron-deficient cells and not by iron-sufficient ones (Fig. 3). No precipitin lines for this protein were observed with ironsufficient cells, whereas these were clearly visible with iron-deficient cells. Appearance of precipitin lines with proteins I, II and IV in both iron-sufficient and iron-deficient cells (results not shown) would again distinguish these three IREPs from protein III. Evidently the synthesis of these proteins is not completely repressed and they are still synthesized to some extent even in iron sufficiency.

\section{Effect of antibodies against IREPs on iron uptake}

Exochelin-mediated iron uptake was followed into $M$. smegmatis grown both iron-deficiently and iron-sufficiently (Table 1). As observed previously (Stephenson \& Ratledge, 1979), there was a four to fivefold increase in the rate of iron uptake into cells grown iron-deficiently over those grown in the presence of excess iron. When suspensions of iron-deficiently grown cells were pre-incubated with normal rabbit serum as a control, no decrease in iron uptake from exochelin was observed (Table 1). In fact, uptake was slightly higher than the control, as in other bacterial systems (Sokol \& Woods, 1984). However, when the same cells were pre-incubated with the antisera raised to each of the four isolated IREPs, inhibition of iron uptake from the mixture of exochelins was observed. This inhibition was only slight (6 to $30 \%)$ with the antisera to proteins I, II and IV but was very pronounced ( 70 to $76 \%$ ) with the antisera raised to protein III. The antiserum raised to protein III was shown to bind to protein III by transferring the 
Table 1. Effect of antibodies against the IREPs on iron uptake from ferri-exochelin, by M. smegmatis

Iron uptake measurements were done as in Methods. Washed suspensions of iron-deficiently and ironsufficiently grown cells were pre-incubated with the antibodies against each of the four IREPs (I, II, III and IV). The results show the values from duplicate experiments; $100 \%$ uptake with iron-deficiently grown cells in the absence of serum was 241200 c.p.m. (mg dry wt) ${ }^{-1}$ and with iron-sufficiently grown cells in the absence of serum it was 51600 c.p.m. (mg dry wt) ${ }^{-1}$. Experiments I and II were done with serum containing $50 \mu \mathrm{g}$ and $90 \mu \mathrm{g}$ total Igs, respectively. ND, Not determined.

\section{Uptake \\ assay \\ system}

No serum

Antiserum against I

Antiserum against II

Antiserum against III

Antiserum against IV

Normal rabbit serum
Iron-deficiently grown cells

$\overbrace{\begin{array}{c}\text { Experiment I } \\ (\% \text { Control })\end{array}}^{\begin{array}{c}\text { Experiment II } \\ (\% \text { Control })\end{array}}$

100

80

94

30

94

110
Iron-sufficiently grown cells

Experiment II

(\% Control)

100

102

104

109

120

ND

purified protein III (see Fig. 2) to a nitrocellulose sheet, incubating with the antiserum and then detecting the well-washed complex with a second antibody linked to horse-radish peroxidase (M. Sritharan, unpublished work). When cells were grown iron-sufficiently and pre-incubated with the antisera to the IREPs, there was no inhibition of iron uptake in any instance (Table 1).

Outer-membrane proteins have been shown to be involved in iron uptake in a variety of organisms (Hollifield \& Neilands, 1978; Ichihara \& Mizushima, 1978). In iron-starved cells of $E$. coli K12, SDS-PAGE of the outer-membrane proteins has revealed the presence of several new proteins with apparent molecular masses in the range 74 to $83 \mathrm{kDa}$ (Braun et al., 1976). Direct involvement of some outer-membrane proteins as receptors in iron uptake was shown by the binding of ${ }^{59} \mathrm{Fe}$-pyochelin (iron-siderophore) to an outer-membrane protein of apparent molecular mass $14 \mathrm{kDa}$ in $P$. aeruginosa (Sokol \& Woods, 1983). Although we could not demonstrate similar binding of ${ }^{55} \mathrm{Fe}$, either as $\mathrm{FeCl}_{3}$ or ferri-exochelin to the isolated IREPs of $M$. smegmatis, possibly due to the denaturing conditions of SDS-electrophoresis, we are nevertheless able to infer, that protein III is probably involved in iron acquisition. The inhibition of exochelin-mediated iron uptake by the antibody raised to protein III is strongly indicative of protein III being involved in iron uptake, particularly as antibody and the isolated protein do physically bind together (see above).

The exact function of protein III, however, is uncertain. It may not be a simple receptor for ferri-exochelin. If it were, it should have been detected in a decreased amount in ironsufficiently grown cells which possess the same active transport system for iron uptake as do iron-deficiently grown cells (Stephenson \& Ratledge, 1979). Further, the antibody to it should have also inhibited iron uptake into the iron-sufficiently grown cells.

This demonstration of the effect of iron on the constitution of cell-envelope proteins of a saprophytic mycobacterium has also been seen with pathogenic species of this genus (M. Sritharan \& C. Ratledge, unpublished work). These results could have important implications in the strategies for overcoming infections caused by these organisms irrespective of what function the IREPs may have. Clearly, in order to develop the most effective vaccines against pathogens, the bacteria being used as the protective agent should themselves be cultivated on iron-deficient medium in order to express a complete set of virulence determinants (see Smith, 1980). The usual choice for a mycobacterial vaccine is $M$. bovis $\mathrm{BCG}$, which has variable success in protecting populations: when adminstered to a person, these bacteria stay localized at the site of injection with little bacterial multiplication taking place. Indeed, any growth of the organism which did occur could be considered to be unlike a natural infection with the inoculum itself likely to contain sufficient iron to sustain several generations. 
The occurrence of specific IREPs may therefore have important practical applications in the treatment of mycobacterial diseases as well as opening up an additional insight into the mechanism of iron acquisition in mycobacteria.

R.M.H., A.J.M.M. and M.S. were supported by research grants from the MRC, SERC and Lepra respectively. We thank Mrs J. Stephenson for laboratory assistance.

\section{REFERENCES}

Braun, V., Hancock, R. E. W., HantKe, K. \& HaRTMANN, A. (1976). Functional organisation of the outer membrane of Escherichia coli: phage and colicin receptors as components of iron uptake system. Journal of Supramolecular Structures 5, 3758.

Brown, M. R. W., ANWar, H. \& Lambert, P. A. (1984). Evidence that mucoid Pseudomonas aeruginosa in the cystic fibrosis lung grows under ironrestricted conditions. FEMS Microbiology Letters 21, 113-117.

Chart, H. \& Griffiths, E. (1985). Antigenic and molecular homology of the ferric enterobactin receptor protein of Escherichia coli. Journal of General Microbiology 131, 1503-1509.

Chart, H., Buck, M., Stevenson, P. \& Griffiths, E. (1986). Iron regulated outer membrane proteins of Escherichia coli: variations in expression due to the chelate used to restrict the availability of iron. Journal of General Microbiology 132, 1373-1378.

Griffiths, E. (1983). Role of the envelope in the survival of bacteria in infection. In Medical Microbiology, vol. 3, pp. 153-177. Edited by C. S. F. Easmon, J. Jeljasewicz, M. R. W. Brown \& P. A. Lambert. London: Academic Press.

GRIFFITHS, E. (1985). Candidate virulence markers. In The Virulence of Escherichia coli (Special Publications no. 13 of the Society for General Microbiology, pp. 193-226. Edited by M. Sussman. London: Academic Press.

Griffiths, E., Stevenson, P. \& Joyce, P. (1983). Pathogenic Escherichia coli express new outer membrane proteins when growing in vivo. FEMS Microbiology Letters 16, 95-99.

Griffiths, E., Stevenson, P., Hale. T. L. \& Formal, S. B. (1985). Synthesis of aerobactin and a 76,000 dalton iron-regulated outer membrane protein by Escherichia coli K-12, Shigella flexneri hybrids and by enteroinvasive strains of Escherichia coli. Infection and Immunity 49, 67-71.

HALL, R. M. (1986). Mycobactins: how to obtain them and how to employ them as chemotaxonomic characters for the mycobacteria and related organisms. Actinomycetes 19, 92-106.

Hall, R. M. \& Ratledge, C. (1982). A simple method for the production of mycobactin, the lipid soluble siderophore, from mycobacteria. FEMS Microbiology Letters 15, 133-136.

HAMES, B. D. \& Rickwood, D. (1981) (eds). Gel Electrophoresis of Proteins: a Practical Approach. Oxford: IRL Press.

Hollifield, W. C., JR \& Neilands, J. B. (1978). Ferric enterobactin transport system in Escherichia coli $\mathrm{K}-12$. Extraction, assay and specificity of the outer membrane receptor. Biochemistry, 17, 1922 1928.
ICHIHARA, S. \& MizUShima, S. (1978). Identification of an outer membrane protein responsible for the binding of the Fe-enterochelin complex of the Escherichia coli cells. Journal of Biochemistry 83, 137140.

Kinoshita, T., Iinuma, F. \& Tsujl, A. (1974). Fluorescent labelling of proteins and a plasma membrane using cycloheptaamylose dansyl chloride complex. Analytical Biochemistry 61, 632-637.

LAM, C., TURNowsKy, F., SCHWARzINGER, F. \& NERUDA, W. (1984). Bacteria recovered without subculture from infected human urines expressed iron-regulated outer membrane proteins. FEMS Microbiology Letters 24, 255-259.

Macham, L. P., Stephenson, M. C. \& Ratledge, C. (1977). Iron transport in Mycobacterium smegmatis: the isolation, purification and function of exochelin MS. Journal of General Microbiology 101, 41-49.

Markwell, M. A. K., HaAs, S. M., Bieber, L. L. \& TOLBERT, N. E. (1978). A modification of the Lowry procedure to simplify protein determination in membrane and lipoprotein samples. Analytical Biochemistry 87, 206-210.

Messenger, A. J. M. \& Ratledge, C. (1982). Iron transport in Mycobacterium smegmatis: uptake of iron from ferric citrate. Journal of Bacteriology 149 , 131-135.

Messenger, A. J. M., Hall. R. M. \& Ratledge, C. (1986). Iron uptake processes in Mycobacterium vaccae R877R, a mycobacterium lacking mycobactin. Journal of General Microbiology 132, 845-852.

NEILANDS, J. B. (1981). Iron absorption and transport in microorganisms. Annual Review of Nutrition 1, 2746.

NeIlands, J. B. (1982). Microbial envelope proteins related to iron. Annual Review of Microbiology 36, 285-309.

RatledGe, C. (1982). Nutrition, growth and metabolism. In The Biology of the Mycobacteria, vol. 1, pp. 185-271. Edited by C. Ratledge \& J. L. Stanford. London: Academic Press.

RATLEDGE, C. \& HALL, M. J. (1971). Influence of metal ions on the formation of mycobactin and salicylic acid in Mycobacterium smegmatis grown in static culture. Journal of Bacteriology 108, 312-319.

Sadhu, C. \& Gopinathan, K. P. (1982). A rapid procedure for the isolation of spheroplasts from Mycobacterium smegmatis. FEMS Microbiology Letters 15, 19-22.

Shand, G. H., Anwar, H., Kadurugamuwa, J., Brown, M. R. W., Silverman, S. H. \& Melling, J. (1985). In rivo evidence that bacteria in urinary tract infection grow under iron-restricted conditions. Infection and Immunity 48, 35-39.

SMith, H. (1980). The effect of environmental conditions in vivo and in vitro on the determinants of 
microbial pathogenicity. In The Molecular Basis of Microbial Pathogenicity, pp. 159-172. Edited by H. Smith, J. J. Skehel \& M. J. Turner. Dahlem Konferenzen Weinheim: Verlag Chemie.

SoKOL, P. A. \& WoODS, D. E. (1983). Demonstration of an iron-siderophore-binding protein in the outer membrane of Pseudomonas aeruginosa. Infection and Immunity 40, 665-669.

SOKOL, P. A. \& WoODS, D. E. (1984). Antibody inhibition of ferripyochelin binding to Pseudomonas aeruginosa cell envelopes. Biochemistry 23,50765080.

SoKoL, P. A. \& Woods, D. E. (1986). Characterisation of antibody to the ferripyochelin binding protein of Pseudomonas aeruginosa. Infection and Immunity 51, 896-900.
Stephenson, M. C. \& Ratledge, C. (1979). Iron transport in Mycobacterium smegmatis: uptake of iron from ferriexochelin. Journal of General Microbiology 101, 193-202.

WANG, A. C. (1982). Methods of immune diffusion, immunoelectrophoresis, precipitation and agglutination. In Antibody as a Tool - the Applications of Immunochemistry pp. 139-163. Edited by J. J. Marchalonis \& G. W. Warr. Chichester: John Wiley.

WARR, G. W. (1982). Purification of antibodies. In Antibody as a Tool - the Applications of Immunochemistry pp. 59-63. Edited by J. J. Marchalonis \& G. W. Warr. Chichester: John Wiley. 